\title{
Transformation and Upgrading of Processing Trade in Guangdong under the New Normal Situation: Status Quo, Problems and Opportunities and Strategic Implications
}

\author{
Haijun Liu \\ Economic School, Jinan University, Guangzhou, China \\ Email: shijiboy18@163.com
}

How to cite this paper: Liu, H.J. (2017) Transformation and Upgrading of Processing Trade in Guangdong under the New Normal Situation: Status Quo, Problems and Opportunities and Strategic Implications. American Journal of Industrial and Business Management, 7, 614-632. https://doi.org/10.4236/ajibm.2017.75046

Received: April 24, 2017

Accepted: May 21, 2017

Published: May 24, 2017

Copyright (C) 2017 by author and Scientific Research Publishing Inc. This work is licensed under the Creative Commons Attribution International License (CC BY 4.0)

http://creativecommons.org/licenses/by/4.0/

\begin{abstract}
Under the new normal situation, the traditional development model processes trade with the feature of "three high and one low". It has been eliminated by the times; to promote the transformation and upgrading of processing trade is imminent. The author takes Guangdong as the research object, which is the coastal processing trade gathering place. Based on the comprehensive analysis of the present situation and development problems of Guangdong processing trade, this paper combines the opportunities and challenges of the transformation and upgrading of Guangdong processing trade under the new normal situation, and puts forward some strategies and revelations to promote the transformation, upgrade, innovation and development of Guangdong's processing trade under the new normal situation. The strategies such as implementing the "Internet plus", "machine substitutions" strategy, to carry out the information and intelligent transformation on the processing trade industry, rely on CEPA and free trade area platform to build processing trade transformation, upgrading and innovative service system, to enhance the "rooted" and "localization" of the processing trade industry, innovative talents training and independent brand building mechanism, to promote the upgrading and introduction, transfer of new linkage of the processing trade and so on.
\end{abstract}

\section{Keywords}

New Normal, Processing Trade of Guangdong, Transformation and

Upgrading, Innovation Development

\section{Introduction}

Since the reform and opening up 30 years, Guangdong processing trade industry 
has taken the extensive model with a high input, high energy consumption, high pollution, and low efficiency. In this industrial model with high energy consumption, low cost driven, Guangdong processing trade industry had experienced up to 30 years of prosperity. Such as in the year of 2015, the import and export amount of Guangdong processing trade is 440.36 billion dollars, accounting for the total import and export trade volume of the proportion of $35.4 \%$. During the year of 2011 to 2015, the average value of Guangdong processing trade import and export is $505.34^{1}$ billion dollars, accounting for the proportion of the total import and export trade volume of the proportion of $37.9 \%{ }^{2}$. Why so? This is mainly due to government's policy support. First of all, China has been opened to the outside world since 1978, and three of its first four special economic zones (Shenzhen, Zhuhai, and Shantou) belong to Guangdong Province. Second, in 1984, two cities (Guangzhou, Zhanjiang) of the first batch of 14 coastal open cities belong to Guangdong Province, both of which undoubtedly promoted the vigorous development of Guangdong processing trade. However, its status of processing and production has been in the U-shaped bottom of global processing trade industry chain bottom; most companies mainly use OEM, ODM production mode to operation. According to statistics, from 2008 to 2014, although accounted for the labor-intensive enterprises in the Guangdong processing trade enterprises had declined, but the average share is still as high as $46.4 \%$, close to 50\% [1]. From 2011 to 2014, the Guangdong province's processing trade enterprises take the production mode of OEM, ODM to exports accounted the amount of total processing trade exports for an average of $52.1 \%^{3}$ and $31.5 \%^{4}$; the sum reached $83.6 \%$, far more than OBM processing trade export, which accounted for (16.4\%). This proves that China's processing trade is in the global production system in the long-term OEM and OEM low-end status.

Wang Zhihong, Chen Xinmin's (2016) [2] opinion show that although the national share had declined slightly, but the province of Guangdong still maintain the status of the large province about processing trade, the total amount of processing trade ranked first in the provinces and cities. However, with the constraints of resources and environment, rising costs, the weakness of independent innovation and investment enterprises, research and development capacity, Guangdong province's processing trade shows the characteristics of "more than not strong”. As we all know, General Secretary Xi Jinping in the party's eighteen and four, five plenary session stressed repeatedly that establish and implement innovation, coordination, green, open, shared development concept, take the initiative to adapt to the new economic development, take the innovation and expand the opening as the driving force, take the international industrial division of labor to adjust and implement the "Made in China 2025" as an opportunity, based on China's national conditions, transformation, innovation and develop-

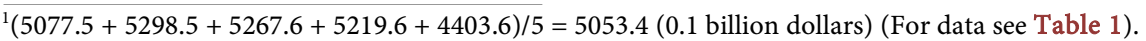
${ }^{2}(38.9+39.4+38.8+36.9+35.4) / 5=37.9(\%)($ For data see Table 1$)$.

${ }^{3}(68+68+58.2+54.8+45.3+37+33.7) / 7=52.1(\%)$ (For data see Table 7$)$.

${ }^{4}(21.9+23.7+26.4+29.6+32.7+47.6+38.5) / 7=31.5(\%)($ For data see Table 7$)$.
} 
ment of the processing trade. This shows that under the economy into the new normal, the traditional development model of processing trade has been difficult to sustain, can't provide sustainable development for China's processing trade development, which has also been recognized by Li Kaijie in 2016 [3]. At the same time, in the background of the new normal economic, to explore of Guangdong province about to promote the transformation and upgrading, innovation and development of processing trade is also the major economic problems during the "13th five year" period, which closely concerned by the CPC Central Committee and the Guangdong provincial government.

At present, processing trade is still an important way for China to participate in international division of labor and international trade. Processing trade still plays a very important role in China's foreign trade development and the development of China's economy. However, since the reform and opening up, China's processing trade industry has become increasingly prominent problems. Such as extensive model with high input, high energy consumption, high pollution, low efficiency. China's processing trade at first mainly relies on the development of relatively large labor advantages, but with the increase in labor costs, this advantage is gradually weakened. Coupled with the recent financial crisis and the RMB appreciation pressure, Transformation and upgrading of processing trade in China is imperative. Therefore, it is of great theoretical and practical significance to study the transformation and upgrading of processing trade in Guangdong, which is the coastal processing trade gathering place. In theory, it can provide policy guidance for the government to formulate relevant policies. In practice, it can provide reference for the transformation and upgrading of the processing trade enterprises in China.

\section{A Review of the Development of Processing Trade in Guangdong Province}

- The total processing trade continues to be the first in the provinces and cities in China.

Table 1 shows the scale of processing trade in Guangdong and the comparison with other provinces in 2011-2015. In 2015, the import and export volume of Guangdong processing trade amounted to 440.36 billion US dollars, accounting for the total import and export trade volume of 35.4\%. From 2011 to 2015, the average value of Guangdong's processing trade import and export value was US \$ 505.34 billion, accounting for $37.9 \%$ of the total import and export volume of processing trade in China, which was higher than that of Zhejiang, Shandong, Shanghai and Jiangsu provinces 34.3, 31.8, 28, 19.7 percentage points. Among them, the average export value of 312.55 billion US dollars, accounting for the proportion of the country's average of $36.8 \%$, respectively, higher than Zhejiang, Shandong, Shanghai, Jiangsu and other provinces and cities accounted for 34, 31.6, 26.7, 19.5 percentage points; The average import value of 19.28 billion US dollars, accounting for the proportion of the national average of $39.8 \%$, respectively, higher than Zhejiang, Shandong, Shanghai, Jiangsu and other provinces and cities accounted for $34.9,32.3,30.3,20$ percentage points. It can be seen that, 
Table 1. 2011-2015 Guangdong processing trade scale and compared with other provinces.

\begin{tabular}{|c|c|c|c|c|c|c|c|}
\hline Year & Region & $\begin{array}{l}\text { Import and } \\
\text { Export }\end{array}$ & Proportion & Export & Proportion & Import & Proportion \\
\hline \multirow{5}{*}{2011} & Guangdong & 5077.5 & 38.9 & 3115.2 & 37.3 & 1962.3 & 41.8 \\
\hline & Shanghai & 1513.8 & 11.6 & 1090.6 & 13.1 & 423.2 & 9.0 \\
\hline & Jiangsu & 2664.9 & 20.4 & 1721.8 & 20.6 & 943.1 & 20.1 \\
\hline & Zhejiang & 532.3 & 4.1 & 360.4 & 4.3 & 172.0 & 3.7 \\
\hline & Shandong & 834.9 & 6.4 & 558.3 & 6.7 & 276.7 & 5.9 \\
\hline \multirow{5}{*}{2012} & Guangdong & 5298.5 & 39.4 & 3249.5 & 37.7 & 2049.0 & 42.6 \\
\hline & Shanghai & 1387.4 & 10.3 & 1015.3 & 11.8 & 372.1 & 7.7 \\
\hline & Jiangsu & 2463.4 & 18.3 & 1602.0 & 18.6 & 861.4 & 17.9 \\
\hline & Zhejiang & 499.7 & 3.7 & 347.0 & 4.0 & 152.7 & 3.2 \\
\hline & Shandong & 810.0 & 6.0 & 544.2 & 6.3 & 265.8 & 5.5 \\
\hline \multirow{5}{*}{2013} & Guangdong & 5267.6 & 38.8 & 3234.4 & 37.6 & 2033.2 & 40.9 \\
\hline & Shanghai & 1292.1 & 9.5 & 943.8 & 11.0 & 348.3 & 7.0 \\
\hline & Jiangsu & 2336.5 & 17.2 & 1500.6 & 17.4 & 835.9 & 16.8 \\
\hline & Zhejiang & 467.0 & 3.4 & 322.5 & 3.7 & 144.5 & 2.9 \\
\hline & Shandong & 788.2 & 5.8 & 526.1 & 6.1 & 262.1 & 5.3 \\
\hline \multirow{5}{*}{2014} & Guangdong & 5219.6 & 36.9 & 3216.3 & 36.4 & 2003.2 & 37.9 \\
\hline & Shanghai & 1258.8 & 8.9 & 896.5 & 10.1 & 362.4 & 6.9 \\
\hline & Jiangsu & 2322.6 & 16.4 & 1466.1 & 16.6 & 856.5 & 16.2 \\
\hline & Zhejiang & 463.4 & 3.3 & 321.5 & 3.6 & 141.8 & 2.7 \\
\hline & Shandong & 847.5 & 6.0 & 547.9 & 6.2 & 299.6 & 5.7 \\
\hline \multirow{5}{*}{2015} & Guangdong & 4403.6 & 35.4 & 2812.3 & 35.3 & 1591.3 & 35.6 \\
\hline & Shanghai & 1134.3 & 9.1 & 801.4 & 10.1 & 332.9 & 7.4 \\
\hline & Jiangsu & 2296.7 & 18.5 & 1480.0 & 18.6 & 816.7 & 18.3 \\
\hline & Zhejiang & 403.9 & 3.2 & 294.5 & 3.7 & 109.4 & 2.4 \\
\hline & Shandong & 744.7 & 6.0 & 492.3 & 6.2 & 252.4 & 5.6 \\
\hline
\end{tabular}

Notes: unless otherwise stated, all the units in the Tables are \$ 100 million and \% except for Table 2 and Table 3. Data source: Department of Commence of Guangdong Province. Data of Tables 4-6 and Table 7 and Table 8 are the same source of Table 1 .

despite a slight decline in the proportion of the country, but Guangdong still maintain the status of the processing trade in the province, the total processing trade ranked first in the provinces and cities.

- The proportion of processing trade in foreign trade has declined in all, but it is still the main form of foreign trade.

Table 4 shows the proportion of processing trade in Guangdong Province in 2011-2015. In 2015, the import and export value of processing trade accounted for $43 \%$ of the province's total import and export volume. On average, from 2011 to 2015, the import and export value of processing trade accounted for 
Table 2. ADF unit root test results for $\ln G D P, \ln E X$ and $\operatorname{lnIM}$.

\begin{tabular}{ccccc}
\hline Variables & Inspection Type $(\mathrm{c}, \mathrm{t}, \mathrm{k})$ & ADF t Values & $5 \%$ Critical Values & Stationartiy \\
\hline $\ln \mathrm{GDP}$ & $(\mathrm{c}, 1,8)$ & -0.9799 & -3.5578 & Non-stationary \\
$\Delta \operatorname{lnGDP}$ & $(\mathrm{c}, 0,8)$ & -2.6865 & -2.6174 & Stationary \\
$\ln \mathrm{EX}$ & $(\mathrm{c}, 0,8)$ & -1.2861 & -3.5530 & Non-stationary \\
$\Delta \operatorname{lnEX}$ & $(\mathrm{c}, 0,8)$ & -7.3366 & -3.5578 & Stationary \\
$\ln \mathrm{MM}$ & $(\mathrm{c}, 0,8)$ & -1.2462 & -3.5530 & Non-stationary \\
$\Delta \ln \mathrm{IM}$ & $(\mathrm{c}, 0,0)$ & -6.4999 & -3.5578 & Stationary \\
\hline
\end{tabular}

Note: $\Delta$ represents first order difference operator. $c, t, k$ of inspection type $(c, t, k)$ represent the constant term, the time trend term and the lag order in the ADF stationary test respectively. (The same below).Data Sources: Eviews 9.0 Analysis Results. Data of Table 4 is the same source of Table 3.

Table 3. Johansen cointegration test results for $\operatorname{lnGDP}, \operatorname{lnEX}$ and $\ln I M$.

\begin{tabular}{|c|c|c|c|c|}
\hline \multirow{2}{*}{ Variables } & Hypothesized & \multirow{2}{*}{ Egien Value } & \multirow{2}{*}{ Trace Statistic } & \multirow{2}{*}{$5 \%$ Critical Value } \\
\hline & No. of CE(s) & & & \\
\hline \multirow{2}{*}{$\operatorname{lnGDP}$ and $\ln E X$} & None & 0.5123 & 30.5526 & 25.8721 \\
\hline & At most 1 & 0.2108 & 7.5743 & 12.5180 \\
\hline \multirow{2}{*}{$\operatorname{lnGDP}$ and $\ln I M$} & None & 0.4175 & 21.1230 & 12.3209 \\
\hline & At most 1 & 0.1128 & 3.8315 & 4.1299 \\
\hline
\end{tabular}

Table 4. The proportion of processing trade in Guangdong Province in 2011-2015.

\begin{tabular}{|c|c|c|c|c|c|c|c|}
\hline Year & Trade Mode & $\begin{array}{l}\text { Import and } \\
\text { Export }\end{array}$ & Proportion & Export & Proportion & Import & Proportion \\
\hline \multirow{2}{*}{2011} & General trade & 3207.4 & 35.1 & 1836.9 & 34.5 & 1370.5 & 35.9 \\
\hline & Processing trade & 5077.3 & 55.6 & 3115.2 & 58.6 & 1962.2 & 51.4 \\
\hline \multirow{2}{*}{2012} & General trade & 3291.9 & 33.5 & 1903.3 & 33.2 & 1388.6 & 33.9 \\
\hline & Processing trade & 5299.1 & 53.9 & 3248.8 & 56.6 & 2050.3 & 50.0 \\
\hline \multirow{2}{*}{2013} & General trade & 3688.1 & 33.8 & 2145.7 & 33.7 & 1542.4 & 33.9 \\
\hline & Processing trade & 5267.2 & 48.2 & 3234.2 & 50.8 & 2033.0 & 44.6 \\
\hline \multirow{2}{*}{2014} & General trade & 4173.2 & 38.6 & 2508.9 & 38.7 & 1664.2 & 38.3 \\
\hline & Processing trade & 5219.6 & 48.3 & 3217.6 & 49.6 & 2004.0 & 46.4 \\
\hline \multirow{2}{*}{2015} & General trade & 4163.1 & 42.1 & 2640.5 & 41.0 & 1522.6 & 40.1 \\
\hline & Processing trade & 4403.6 & 43 & 2812.3 & 43.7 & 1591.3 & 41.9 \\
\hline
\end{tabular}

Table 5. The share of processing trade in various types of enterprises in Guangdong from 2011 to 2014.

\begin{tabular}{cccccc}
\hline Year & $\begin{array}{c}\text { Foreign-Funded } \\
\text { Enterprise }\end{array}$ & $\begin{array}{c}\text { State-Owned } \\
\text { Enterprise }\end{array}$ & $\begin{array}{c}\text { Collective } \\
\text { Enterprise }\end{array}$ & $\begin{array}{c}\text { Private } \\
\text { Enterprise }\end{array}$ & Others \\
\hline 2011 & 81.1 & 6.4 & 1.0 & 8.0 & 3.5 \\
2012 & 79.5 & 4.5 & 0.6 & 9.7 & 5.8 \\
2013 & 81.1 & 3.5 & 0.5 & 9.9 & 5.5 \\
2014 & 81.2 & 2.6 & 0.5 & 11.8 & 3.9 \\
\hline
\end{tabular}


Table 6. The import and export of major trading partners in Guangdong processing trade between 2011 and 2014.

\begin{tabular}{|c|c|c|c|c|c|c|c|}
\hline Year & Region & $\begin{array}{c}\text { Import and } \\
\text { Export }\end{array}$ & Proportion & Export & Proportion & Import & Proportion \\
\hline \multirow{4}{*}{2011} & Hong Kong & 1458.0 & 40.9 & 1432.1 & 53.2 & 25.9 & 2.9 \\
\hline & $\begin{array}{l}\text { the United } \\
\text { States }\end{array}$ & 644.0 & 18.0 & 591.9 & 22.0 & 52.1 & 5.9 \\
\hline & Japan & 407.8 & 11.4 & 182.8 & 6.8 & 225.1 & 25.6 \\
\hline & Others & 1059.1 & 29.7 & 482.9 & 18.0 & 576.2 & 65.5 \\
\hline \multirow{4}{*}{2012} & Hong Kong & 1520.1 & 41.2 & 1496.9 & 53.3 & 23.2 & 2.6 \\
\hline & $\begin{array}{l}\text { the United } \\
\text { States }\end{array}$ & 632.7 & 17.2 & 582.7 & 20.8 & 50.0 & 5.7 \\
\hline & Japan & 426.2 & 11.6 & 200.2 & 7.1 & 226.0 & 25.6 \\
\hline & Others & 1109.4 & 30.1 & 526.9 & 18.8 & 582.5 & 66.1 \\
\hline \multirow{4}{*}{2013} & Hong Kong & 1508.0 & 41.3 & 1482.8 & 55.1 & 25.2 & 2.9 \\
\hline & $\begin{array}{l}\text { the United } \\
\text { States }\end{array}$ & 616.6 & 16.9 & 567.1 & 21.1 & 49.6 & 5.6 \\
\hline & Japan & 399.1 & 10.9 & 194.0 & 7.2 & 205.1 & 23.3 \\
\hline & Others & 1124.7 & 30.8 & 536.6 & 19.9 & 588.1 & 66.9 \\
\hline \multirow{4}{*}{2014} & Hong Kong & 1388.5 & 35.7 & 1372.4 & 46.8 & 16.0 & 1.7 \\
\hline & $\begin{array}{l}\text { the United } \\
\text { States }\end{array}$ & 627.9 & 16.1 & 574.1 & 19.6 & 53.8 & 5.6 \\
\hline & Japan & 364.5 & 9.4 & 174.4 & 5.9 & 190.1 & 19.8 \\
\hline & Others & 1121.8 & 28.8 & 535.3 & 18.2 & 586.5 & 61.2 \\
\hline
\end{tabular}

Table 7. The change of production mode of Guangdong processing trade enterprises from 2008 to 2014 .

\begin{tabular}{ccccccccc}
\hline Mode of Production & Main Indicators & 2008 & 2009 & 2010 & 2011 & 2012 & 2013 & 2014 \\
\hline $\begin{array}{c}\text { Original Equipment } \\
\text { Manufacturer (OEM) }\end{array}$ & Amount of exports & 1776.1 & 1518.3 & 1604.4 & 1707.8 & 1472.0 & 1197.3 & 1080.0 \\
Proportion & 68.0 & 68.0 & 58.2 & 54.8 & 45.3 & 37.0 & 33.7 \\
$\begin{array}{c}\text { Original Design } \\
\text { Manufacturer (ODM) }\end{array}$ & Amount of exports & 572.6 & 527.9 & 726.6 & 921.4 & 1061.2 & 1538.61235 .1 \\
Original Brand & Proportion & 21.9 & 23.7 & 26.4 & 29.6 & 32.7 & 47.6 & 38.5 \\
Manufacture (OBM) & Proportion & 10.1 & 8.3 & 15.4 & 15.5 & 22 & 15.4 & 17.8 \\
\hline
\end{tabular}

$49.8 \%$ of the total import and export volume of the province, which was 13.2 percentage points higher than that of general trade. Among them, the processing trade exports accounted for the proportion of the province's total export value of $51.9 \%$, which was 15.6 percentage points higher than that of general trade. Imports accounted for the proportion of the province's total imports of $46.8 \%$, higher than the general trade accounted for 10.4 percentage points. This shows that in recent years, Guangdong processing trade in the province's foreign trade accounted for a slight decline in the amount, but still dominates, is still the main way of Guangdong's foreign trade. 
Table 8. The development of processing trade in different regions of Guangdong from 2011 to 2014.

\begin{tabular}{|c|c|c|c|c|c|c|c|}
\hline Year & Region & $\begin{array}{l}\text { Amount of } \\
\text { import } \\
\text { and export }\end{array}$ & Proportion & $\begin{array}{l}\text { Amount } \\
\text { of export }\end{array}$ & Proportion & $\begin{array}{l}\text { Amount } \\
\text { of import }\end{array}$ & Proportion \\
\hline \multirow[b]{2}{*}{2011} & $\begin{array}{l}\text { Pearl River } \\
\text { Delta region }\end{array}$ & 4951.9 & 97.5 & 3035.1 & 97.4 & 1916.7 & 97.7 \\
\hline & $\begin{array}{l}\text { Eastern, Western } \\
\text { and Northern } \\
\text { Guangdong }\end{array}$ & 125.6 & 2.5 & 80.1 & 2.6 & 45.6 & 2.3 \\
\hline \multirow[b]{2}{*}{2012} & $\begin{array}{l}\text { Pearl River } \\
\text { Delta region }\end{array}$ & 5175.4 & 97.7 & 3166.8 & 97.5 & 2008.6 & 98.0 \\
\hline & $\begin{array}{l}\text { Eastern, Western } \\
\text { and Northern } \\
\text { Guangdong }\end{array}$ & 123.7 & 2.3 & 82.0 & 2.5 & 41.7 & 2.0 \\
\hline \multirow[b]{2}{*}{2013} & $\begin{array}{l}\text { Pearl River } \\
\text { Delta region }\end{array}$ & 5135.1 & 97.5 & 3149.1 & 97.4 & 1986.0 & 97.7 \\
\hline & $\begin{array}{l}\text { Eastern, Western } \\
\text { and Northern } \\
\text { Guangdong }\end{array}$ & 132.2 & 2.5 & 85.2 & 2.6 & 47.0 & 2.3 \\
\hline \multirow[b]{2}{*}{2014} & $\begin{array}{l}\text { Pearl River } \\
\text { Delta region }\end{array}$ & 5086.1 & 97.4 & 3127.9 & 97.3 & 1958.1 & 97.8 \\
\hline & $\begin{array}{l}\text { Eastern, Western } \\
\text { and Northern } \\
\text { Guangdong }\end{array}$ & 133.5 & 2.6 & 88.4 & 2.7 & 45.1 & 2.2 \\
\hline
\end{tabular}

- Foreign-funded enterprises mainly engaged in Hong Kong, Macao and Taiwan-funded enterprises are the main force in the development of processing trade.

The development of processing trade in Guangdong is closely related to the entry of foreign capital, especially Hong Kong, Macao and Taiwan (Chen En, Liu Qing, 2007) [4]. It can be said that Guangdong processing trade started in Hong Kong, Macao and Taiwan to undertake the transfer of industry, the vigorous development of processing trade to a large extent benefited from Hong Kong, Macao and Taiwan region's industrial cooperation. At present, the processing trade in Guangdong has formed the situation of foreign invested enterprises, especially the Hong Kong, Macao and Taiwan funded enterprises.

Table 5 shows the share of processing trade in various types of enterprises in Guangdong from 2011 to 2014. From 2011 to 2014, the average amount of processing trade in foreign-invested enterprises accounted for $80.7 \%$ of the total processing trade, which were 70.9 and 76.66 percentage points higher than that of state-owned enterprises and private enterprises respectively. As of the end of 2015, foreign-funding processing trade enterprises have about 20,000, accounting for $80.4 \%$ of the province's total number of processing trade enterprises. 
Foreign-funded enterprises in the processing trade in Guangdong occupy a dominant position, reflecting the low degree of localization of processing trade in Guangdong, local production supporting capacity of the weak.

- Processing trade market sales are mainly concentrated in Hong Kong, the United States and Japan.

Table 6 shows the import and export of major trading partners in Guangdong processing trade between 2011 and 2014. In 2014, with the Guangdong processing trade import and export of the top three trading partners followed by Hong Kong, the United States, Japan, import and export volume were 138.85 billion US dollars, 62.79 billion US dollars and 36.45 billion US dollars, accounting for the province's total import and export trade volume Respectively, $35.7 \%, 16.1 \%$ and $9.4 \%$, down 5.2, 1.9 and 2.1 percentage points from 2011; the three accounted for 61.2\%, down 9.2 percentage points from 2011. In 2011, the average value of import and export of Guangdong and Hong Kong, the United States and Japan was $39.8 \%, 17.1 \%$ and $10.8 \%$ respectively. The average share of the exports was $52.1 \%, 20.9 \%$ and $6.8 \%$ respectively. The average share of imports was $2.5 \%, 5.7 \%$ and $23.6 \%$, respectively. It can be seen that Hong Kong, the United States and Japan are the most important trading partners of Guangdong processing trade. Hong Kong is the largest processing trade partner and the largest processing trade export market.

\section{An Empirical Analysis of the Relationship between the Development of Processing Trade and Economic Growth in Guangdong}

The original variables of empirical analysis in this paper are "Gross Domestic Product of Guangdong Province", Imports and Exports.

\subsection{An Analysis of the Contribution of Guangdong Processing Trade to Economic Growth}

This paper refers to the practice of scholars such as Lin Yifu and Li Yongjun (2001) [5], and uses the Keynesian model under open economic conditions to measure the pulling effect of processing trade on economic growth. According to this model, economic growth $(Y)$ is driven by consumption $(C)$, investment (I), net exports ( $N X=X-M)$ troika. That is

$$
Y=C+I+(X-M)
$$

According to the formula, we can obtain the increment identity:

$$
\Delta Y=\Delta C+\Delta I+\Delta X-\Delta M=\Delta C+\Delta I+\Delta N X
$$

Since net exports $(N X)$ can be divided into net exports of processing trade ( $N X 1)$ and net exports of general trade ( $N X 2$ ), that is, $N X=N X 1+N X 2$. So, the above formula can be written as

$$
\begin{aligned}
\Delta Y & =\Delta C+\Delta I+\Delta X-\Delta M \\
& =\Delta C+\Delta I+\Delta N X \\
& =\Delta C+\Delta I+\Delta N X 1+\Delta N X 2
\end{aligned}
$$


Therefore,

$$
\begin{aligned}
\frac{\Delta Y}{Y} & =\frac{\Delta C}{Y}+\frac{\Delta I}{Y}+\frac{\Delta N X 1}{Y}+\frac{\Delta N X 2}{Y} \\
& =\frac{\Delta C}{Y} \cdot \frac{C}{C}+\frac{\Delta I}{Y} \cdot \frac{I}{I}+\frac{\Delta N X 1}{Y} \cdot \frac{N X 1}{N X 1}+\frac{\Delta N X 2}{Y} \cdot \frac{N X 2}{N X 2} \\
& =\frac{\Delta C}{C} \cdot \frac{C}{Y}+\frac{\Delta I}{I} \cdot \frac{I}{Y}+\frac{\Delta N X 1}{N X 1} \cdot \frac{N X 1}{Y}+\frac{\Delta N X 2}{N X 2} \cdot \frac{N X 2}{Y}
\end{aligned}
$$

From the above formula, the contribution of processing trade to GDP $=\Delta N X 1 / \Delta Y=$ the increase in net exports of processing trade/the increases in GDP, that is, how much of the increase in GDP is contributed by processing trade.

The pull of processing trade to GDP growth $=(\Delta N X 1 / \Delta Y) \cdot(\Delta Y / Y)=$ The contribution of processing trade to GDP $\times$ GDP growth rate, that is, how many percentage points in GDP growth is pulled by the processing trade.

According to the above formula, we can calculate the contribution of processing trade to economic growth in Guangdong. The results are as follows:

The results show that in addition to a few years ( 7 years), there are 28 years of both contribution of processing trade to economic growth and degree of pull being positive in the Guangdong (see Table 9). During this period, the average annual contribution of processing trade net exports to GDP in Guangdong was $11.6 \%$, higher than the national average of 5.4 percentage points ${ }^{5}$ [6], that is, during this period, $11.6 \%$ of the average annual increase in GDP in Guangdong (2073.2 billion yuan) was contributed by the net export increment of processing trade. The average annual pull degree of net exports of processing trade to GDP growth rate was $1.6 \%$, higher than the national average of 0.8 percentage points. That is, the average annual growth rate of GDP in Guangdong during this period (12.9\%), $1.6 \%$ is driven by net exports of processing trade. This shows that Guangdong processing trade has a significant role in promoting economic growth.

\subsection{A Quantitative Analysis of Guangdong's Processing Trade Promoting Economic Growth}

Based on the export of processing trade (EX) the import of processing trade (IM) and "the gross domestic product of Guangdong" (GDP), the cointegration equation and the error correction model are constructed to analyze the economic growth effect of the processing trade on Guangdong. The data of Guangdong's gross domestic product (GDP) are from Guangdong Statistics Bureau; the data of processing trade export (EX) and processing trade import (IM) are from Guangdong Statistical Yearbook for 1981-215. In order to eliminate the heteroscedasticity, take the natural logarithm of each variable, denote $\operatorname{lnGDP}, \operatorname{lnEX}$ and lnIM respectively.

\footnotetext{
${ }^{5}$ According to the results of Wan Yi, Luo Jianhong (2015), the average contribution rate of the national processing trade net exports to GDP was $6.2 \%$, the average pull of processing trade net export to the growth rate of GDP was $0.8 \%$.
} 
Table 9. Contribution of Guangdong processing trade to economic growth from 1981 to 2015.

\begin{tabular}{|c|c|c|c|c|c|}
\hline Year & $\begin{array}{c}\text { Net Export } \\
\text { Increment of } \\
\text { Processing Trade }\end{array}$ & $\begin{array}{c}\text { GDP } \\
\text { Increment }\end{array}$ & $\begin{array}{l}\text { The Contribution } \\
\text { of Processing } \\
\text { Trade to GDP }\end{array}$ & $\begin{array}{c}\text { GDP } \\
\text { Growth Rate }\end{array}$ & $\begin{array}{l}\text { The Pull Degree of } \\
\text { Processing Trade } \\
\text { to GDP Growth }\end{array}$ \\
\hline 1981 & -3.3 & 40.7 & -8.1 & 9.0 & -0.7 \\
\hline 1982 & 0.0 & 49.6 & 0.1 & 12.0 & 0.0 \\
\hline 1983 & 3.9 & 28.8 & 13.5 & 7.3 & 1.0 \\
\hline 1984 & 9.5 & 90.0 & 10.6 & 15.6 & 1.6 \\
\hline 1985 & -5.3 & 118.6 & -4.5 & 18.0 & -0.8 \\
\hline 1986 & -15.1 & 90.1 & -16.8 & 12.7 & -2.1 \\
\hline 1987 & 5.3 & 179.2 & 2.9 & 19.6 & 0.6 \\
\hline 1988 & -4.5 & 308.7 & -1.4 & 15.8 & -0.2 \\
\hline 1989 & 97.8 & 226.0 & 43.3 & 7.2 & 3.1 \\
\hline 1990 & 66.8 & 177.6 & 37.6 & 11.6 & 4.3 \\
\hline 1991 & 43.2 & 334.3 & 12.9 & 17.7 & 2.3 \\
\hline 1992 & 34.7 & 554.2 & 6.3 & 22.1 & 1.4 \\
\hline 1993 & 94.1 & 1021.7 & 9.2 & 23.0 & 2.1 \\
\hline 1994 & 254.2 & 1149.7 & 22.1 & 19.7 & 4.4 \\
\hline 1995 & 249.1 & 1314.0 & 19.0 & 15.6 & 2.9 \\
\hline 1996 & 284.0 & 901.9 & 31.5 & 11.3 & 3.5 \\
\hline 1997 & 204.0 & 939.6 & 21.7 & 11.2 & 2.4 \\
\hline 1998 & 242.5 & 756.3 & 32.1 & 10.8 & 3.5 \\
\hline 1999 & -40.7 & 719.8 & -5.7 & 10.1 & -0.6 \\
\hline 2000 & 334.5 & 1490.6 & 22.4 & 11.5 & 2.6 \\
\hline 2001 & 301.8 & 1298.0 & 23.3 & 10.5 & 2.4 \\
\hline 2002 & 133.3 & 1463.2 & 9.1 & 12.4 & 1.1 \\
\hline 2003 & 792.9 & 2342.2 & 33.9 & 14.8 & 5.0 \\
\hline 2004 & 716.7 & 3020.0 & 23.7 & 14.8 & 3.5 \\
\hline 2005 & 952.9 & 3692.8 & 25.8 & 14.1 & 3.6 \\
\hline 2006 & 879.2 & 4030.4 & 21.8 & 14.8 & 3.2 \\
\hline 2007 & 1130.1 & 5189.3 & 21.8 & 14.9 & 3.2 \\
\hline 2008 & 568.9 & 5019.7 & 11.3 & 10.4 & 1.2 \\
\hline 2009 & -1162.2 & 2685.9 & -43.3 & 9.7 & -4.2 \\
\hline 2010 & 932.1 & 6530.5 & 14.3 & 12.4 & 1.8 \\
\hline 2011 & 345.1 & 7197.2 & 4.8 & 10.0 & 0.5 \\
\hline 2012 & 118.5 & 3857.6 & 3.1 & 8.2 & 0.3 \\
\hline 2013 & -126.3 & 5096.1 & -2.5 & 8.5 & -0.2 \\
\hline 2014 & 7.6 & 5628.0 & 0.1 & 7.8 & 0.0 \\
\hline 2015 & 478.6 & 5020.5 & 9.5 & 8.0 & 1.6 \\
\hline
\end{tabular}

Note: the net export increment of processing trade was converted into Renminbi according to the exchange rate at the end of each year. Data Sources: "Guangdong Statistical Yearbook (calendar year)" and "the number of Guangdong sixty years". 


\section{- Unit Root Test}

An ADF unit root test was performed on all variables. Test results Table 2 shows that $\operatorname{lnGDP}, \operatorname{lnEX}$ and $\operatorname{lnIM}$ variables are non-stationary at a significant level of 5\%, and their first-order differences are stationary. So, the pre-requisites for co-integration test are satisfied.

According to the results of Wan Yi and Luo Jianhong (2015), the average contribution rate of net export of processing trade to GDP is $6.2 \%$, and the average pull rate of net export of processing trade to GDP growth rate is $0.8 \%$.

- Cointegration Test

The cointegration relationship between $\operatorname{lnGDP}$ and $\operatorname{lnEX}$, lnGDP and lnIM was examined by Johansen cointegration method. The results of cointegration test showed that there was only one cointegration relationship between lnGDP and $\operatorname{lnEX}, \operatorname{lnGDP}$ and $\operatorname{lnIM}$ at the 5\% significance level. The results showed that the long-term equilibrium equations of $\operatorname{lnGDP}$ and $\operatorname{lnEX}$, lnGDP and $\operatorname{lnIM}$ respectively are:

$$
\begin{gathered}
\ln \mathrm{GDP}=0.7382 \ln \mathrm{EX} \\
\mathrm{t} \text { value }(5.462) \\
\ln \mathrm{GDP}=0.4251 \ln \mathrm{IM} \\
\mathrm{t} \text { value }(8.062)
\end{gathered}
$$

From the cointegration equation, there is a long-term stable relationship between the export of processing trade, the import of processing trade and "the GDP of Guangdong" in the long run. The elasticity of the export of processing trade to Guangdong's GDP is 0.7382 , higher than the national average of 0.2025 percentage points (Xiao Yang, Chen Miaohong, 2015) ${ }^{6}$ [7]. In other words, every $1 \%$ increase in processing trade exports will boost GDP growth of $0.7382 \%$ in Guangdong. The elasticity of the imports of processing trade to Guangdong's GDP is 0.4251 . In other words, every $1 \%$ increase in processing trade imports will drive GDP growth of $0.4251 \%$ in Guangdong, higher than the national average of 0.0265 percentage points ${ }^{6}$.

\section{- Error Correction Model}

Since the natural logarithm of Guangdong's GDP (lnGDP) will be adjusted with the natural logarithm of the processing trade exports (lnEX) and the natural logarithm of the processing trade imports (lnIM) in the short term, it is necessary to further establish the error correction model.

$$
\begin{gathered}
\Delta \ln \mathrm{GDP}_{t}=0.0626-0.1412 \mathrm{ecm}_{t-1}+0.1032 \Delta \ln \mathrm{EX}_{t} \\
\text { t value }(-4.4666)(2.0891)
\end{gathered}
$$

The above formula is the error correction model between $\operatorname{lnGDP}$ and $\operatorname{lnEX}$. The numbers in parentheses are the $t$ statistic values of each variable; ecm is the error correction term, derived from the cointegration relation. The coefficient $(-0.1412)$ of the correction term ecm is less than zero, which is consistent with the principle of the reverse correction mechanism. The results of the model es-

\footnotetext{
${ }^{6}$ According to Xiao Yang and Chen Miaohong (2013), the elasticity of export and import of processing trade to GDP is respectively 0.5357 and 0.3986 .
} 
timation show that the short-term fluctuation of $\operatorname{lnGDP}$ is affected by the short-term change of $\operatorname{lnEX}$ in terms of the short-term dynamic relationship. LnEX annual growth of $1 \%$ drives increase of lnGDP annual growth of $0.1032 \%$. When the short-term volatility deviates from the long-term equilibrium, the non-equilibrium error will be revised at a rate of 0.1412 for Guangdong's economic growth. This shows that the export of processing trade has positive feedback mechanism on Guangdong's GDP, which is conducive to promoting economic growth in Guangdong.

\section{The Main Problems in the Transformation and Upgrading of Guangdong Processing Trade}

- The sustainable development of processing trade is constrained by the shortage of resources and the rising cost of production factors.

At present, Guangdong accounts for only $1.85 \%$ of the country's land area, but to undertake the country's total $12 \%$ of the total wastewater, $14 \%$ of urban sewage, $9 \%$ of industrial wastewater, $4.4 \%$ of industrial waste, $5.5 \%$ of industrial sulfur dioxide emissions and $7.3 \%$ of the chemical oxygen demand emissions. It can be seen that environmental problems have become increasingly prominent. Due to the constraints of resources and environment, rising production costs and the weakness of environmental bearing capacity (Fan Maoqing and Huang Wei, 2014) [8], the traditional development model of Guangdong's processing trade has become more and more difficult.

- Processing trade in the global production system in the OEM and OEM low-end status.

Most of the processing trade enterprises in Guangdong are dependent on leading manufacturers and high-level suppliers of the global production network to grow up. Narrow in the secondary processing level of technology applications, will inevitably lead to the shortage of new products and key technology development power and the lack of original innovation ability. Table 7 shows the change of production mode of Guangdong processing trade enterprises from 2008 to 2014. From 2011 to 2014, enterprise exports of processing trade in Guangdong with OEM, ODM way accounted for the total amount of the processing trade export for an average of $52.2 \%$ and $31.5 \%$; the sum of the two reached $83.6 \%$, far more than the OBM way of processing trade exports accounted for $16.4 \%$. This kind of dependency characteristic of processing trade enterprises on technological capability and technological structure is seriously restricting the pace and space of transformation and upgrading of processing trade.

- The processing trade enterprises which take the foreign capital enterprises in Hong Kong and Macao as the main body, are lack of technical basis and internal impetus for the transformation and upgrading.

At present, the processing trade of Guangdong has formed the situation of foreign invested enterprises, especially those of Hong Kong and Macao. Foreign-funded enterprises in the processing trade in Guangdong occupy a domi- 
nant position, reflecting the low degree of localization of processing trade in Guangdong, local production supporting capacity of the weak. In the exogenous development mode, the vast majority of processing trade enterprises in Guangdong to the vertical division of labor mainly through the parent company or affiliated companies can complete the raw materials from the final product processing and manufacturing process, and the low degree of localization, the industrial chain is short; it is difficult to establish horizontal cooperation, and the integration of local enterprises is low. Therefore, the survival and development of most of the processing trade enterprises on Guangdong province is highly dependent on the overseas parent company. The power of decision-making about technological innovation and transformation is mastered by the overseas parent company so that their own lack the technical basis and internal motivation of transformation and upgrading.

- Processing trade industry transfer mechanism is not perfect.

Guangdong processing trade development imbalance is prominent; the industry is highly concentrated in the Pearl River Delta region. Table 8 shows the development of processing trade in different regions of Guangdong from 2011 to 2014. On average, the import and export volume of processing trade in the Pearl River Delta region accounted for $97.5 \%$ of the total import and export volume of the province from 2011 to 2014. Some of the processing trade industries in the Pearl River Delta region, especially the traditional labor-intensive industries, began to seek the transfer. because of the east and west wings and mountains to undertake the Pearl River Delta industrial transfer conditions are not yet mature, it is difficult to form an effective processing and manufacturing transfer and undertake mechanism which to a certain extent, have slowed the pace of transformation and upgrading of processing trade in the province.

\section{Domestic and International Environment and Challenges Facing the Transformation and Upgrading of Processing Trade in Guangdong under the New Normal State}

- The new economic normalization puts forward the adaptability requirements for the transformation, upgrading and innovation of Guangdong processing trade.

In recent years, with the economy into the new normal state: the growth rate from high-speed growth to high-speed growth, production from extensive to intensive, industrial structure from the low-end to the high-end conversion, factor-driven growth into innovation-driven growth, from the basic role of the market to play a decisive role in resource allocation. In the new economic normal, as Yang Zhaoxiang (2014) [9] proposed that "three high and one low: high input, high energy consumption, high pollution, low value-added" development model of processing trade is more and more difficult to succeed so that transformation and upgrading is imminent. To make the economy more efficient, healthier and more sustainable, it is necessary to promote the transformation and upgrading of processing trade. The elimination of low-end production, the 
implementation of high-end products, the lengthen of industrial chain is to improve the quality and efficiency of the processing trade industry, is the objective requirement to initiatively adapt to the new economic normal.

- Transformation and upgrading of processing trade in Guangdong is in the historical intersection time of a new round of globalization and China's reform and opening up.

In the context of service trade becoming the engine of international trade growth, the global economy has entered an era of service economy. At present, the service trade has become a "short board" of China's foreign trade". One of the reasons: China's service industry in the open market in the middle and high level, but compared with the countries with higher income levels; there is still much room for improvement in service openness. In the future transformation of processing trade, we need start with the international service industry globalization and focus on the open of the service trade and service industry market. In the process of opening up, we should promote the process of global free trade focusing on trade in services, create favorable conditions for economic transformation and upgrading in the process of opening up, and actively create a more effective global industrial chain and value chain.

- Transformation and upgrading of processing trade in Guangdong is facing a new round of technological revolution and industrial revolution in the world.

The Internet intelligent production as a representative of a new round of technology boom sweep the globe which requires the implementation of innovation driven development strategy in China, to change the past OEM production and processing mode, Take the brand and technology development route.

- The formation of taking service industry as the main industrial structure is the strategic choice of Guangdong's economic transformation and upgrading.

At present, China is in a critical period of this economic transformation, the growing demand for economic services. Whether it is economic growth to maintain high-speed or economic structure into the high-end level, to a large extent depends on the formation of the service industry as the main body of the industrial structure. First of all, under the background of the new round of industrial revolution, the deepening of economic reform requires the development of service-oriented manufacturing industry and accelerating the formation of the deep integration of industry and service industry. Second, the scale of urbanization to the transformation and upgrading of population urbanization provides a huge space for the development of living services. Finally, China is in a critical period of transformation and upgrading of the consumption structure, the consumption structure of urban and rural residents is upgrading from material consumption to service consumption, which will form the internal driving force of economic service. Therefore, the key point of Guangdong economic transformation and upgrading of the next step is the formation of the industrial structure in service industry as the main body, to speed up the development of taking design, research as the leading production service industry and to realize the transformation of production-oriented manufacturing to service-oriented 
manufacturing.

\section{The Strategy Enlightenment of Guangdong's Processing Trade Transformation and Upgrading and Innovation Development under the New Economic Conditions}

- The strategies such as implement the "Internet plus", "machine substitutions" strategy, to carry out the information and intelligent transformation on the processing trade industry.

Currently, the economy in Guangdong is in a critical period of transformation and upgrading, Innovation-driven being new economic growth momentum under the new normal. The implementation of "Internet plus", "machine substitution" strategy, the transformation of traditional processing and manufacturing industry, can break the information asymmetry and reduce production and transaction costs, which plays an important role on promoting the professional division of labor and improving labor productivity, are also an effective way to promote the transformation and upgrading of traditional processing and manufacturing industry. The implementation of the "Internet plus" strategy of informatization of the processing trade, is the use of cloud computing, the Internet, big data and other latest technologies to production service industry into the manufacturing sector, to play the role of the Internet service platform, optimize the industrial chain and the service chain, accelerate cross-border industrial upgrading of processing trade. This requires us to break the boundaries of the original format of the processing trade industry from the aspects of product form, sales channel, service mode, profit model and brand building, and support the application of enterprise intelligent results and transform the enterprise production process and business process. The implementation of the "machine substitutions" strategy for intelligent transformation of processing trade is to speed up the pace of the manufacturing industry, to improve the traditional mode of production and the introduction of high technology, to enhance the processing level, to focus on combination of automation production and production efficiency.

- Keep up with the pace of global manufacturing services to promote the processing of Guangdong manufacturing services.

From the international point of view, manufacturing service is an important way of the industrial transformation and upgrading, improving quality and efficiency, strengthening services and improving the international market competitiveness (Liu Welin, 2015) [10]. Guangdong should follow this new trend, and actively develop service-oriented manufacturing and production services, and promote the internationalization process of processing and manufacturing industry. There are two modes of servitization of manufacturing industry: one mode is to emphasize the servitization of core technology. Guide the processing trade enterprises to further involved in the design, manufacture, operation and maintenance, marketing, training and other industrial chain business, through the industrial chain restructuring, dilute processing and manufacturing, focusing 
on the implementation of producer services chain. Another mode is diversified in the main business. The government should encourage and support the processing trade enterprises to grasp the latest industry dynamics, weaken or even withdraw from the traditional low-end business. Another way is to promote the processing trade enterprises in the high-end value chain of service trade. The development of service outsourcing is an important way to promote the extension of processing trade to the value chain and to enhance the status of Guangdong's processing trade in the global industrial chain. In recent years, many multinational companies focus on manufacturing high-end, by strengthening product development and technological innovation, manufacturing, product design and other aspects to improve core competitiveness, and logistics, after-sales service and other service links to expand outward service outsourcing approach. To this end, Guangdong should be the development of service outsourcing as an important part of the transformation and upgrading of processing trade, and guide the processing trade enterprises to actively undertake international service outsourcing, and strive to cultivate and develop warehousing, logistics, distribution and after-sales service business to speed up the global value chain Value-added downstream service links extend, expand the profit margins.

- Relying on the free service area public service platform and CEPA framework, to build the innovation service system of transformation and upgrading of processing trade.

As a "test field" for deepening reform and institutional innovation in China, Guangdong Free Trade Area does not aim at the development of processing trade, but it undertakes the service elements at both ends of the chain of processing trade and supports the important mission of supporting the transformation and upgrading of processing trade. Next, we should make full use of the free trade area platform, the establishment of an innovative service system conducive to the transformation and upgrading of processing trade. Specifically, from two aspects: on the one hand, to adapt to the processing trade enterprises to carry out technological innovation, technological transformation, to achieve the needs of transformation and upgrading, in the Guangdong Free Trade Area to build technology innovation service platform, make full use of and carry out in technology research and development, industrial design, Intellectual property on the comparative advantages and trade cooperation, to create high-end research and development, high-end service industry cluster development area. On the other hand, the Guangdong Free Trade Area to expand the service industry to Hong Kong and Macao to open the first pilot system mechanism to speed up the introduction of Hong Kong and Macao intermediary services, accelerate the construction of processing trade quality certification, test testing, e-commerce, information services and other public service platform. In addition, relying on CEPA and Guangdong Free Trade Area are to establish market rules in a line with Hong Kong and Macao, to create a favorable environment for the transformation and upgrading of processing trade business environment. For the central support, will further implement the CEPA "first try" pre-approval 
authority and market access rights as a whole package, decentralized and authorized to the Guangdong provincial government, and to allow Guangdong to develop CEPA and its supplementary agreement implementation details for Guangdong further Expand the service industry to Hong Kong and Macao open, the introduction of modern service industry to create a favorable policy environment. In the Guangdong Free Trade Area, the implementation of the "preentry national treatment + negative list" management model, speed up the construction of Hong Kong and Macao and international standards system, promote the Guangdong-Hong Kong and Macao service industry planning convergence, service agencies cross-border establishment and service elements of resources to facilitate the flow, In order to promote the operation of Hong Kong and Macao in Guangdong enterprises processing trade enterprises gradually to the marketing, brand design and other high-end links to the global value chain, to speed up the creation of "Guangdong service" brand, docking global processing trade.

- Strengthening the "embeddedness" and "localization" of the processing trade industry, the cultivation of innovative talents and the construction of independent brands.

To promote the local domestic enterprises and foreign trade enterprises docking industry chain, and enhance the processing trade industry, "embeddedness" and "localization". Guangdong Provincial Government should actively guide foreign-funded processing trade enterprises to improve the local procurement rate of intermediate goods, while enhancing the domestic enterprises to undertake high value-added industrial chain capacity to enhance the development of processing trade on the local industry leading role. It should be given full play to the trade associations, chambers of Commerce and other industry organizations to carry out investment, and enhance the regional embeddedness of processing trade clusters. On the other hand, to encourage local enterprises to participate in the international division of labor by way of processing trade, support the strength of the local leading enterprises into the integration of industrial chain, transnational corporation production management system, set up $\mathrm{R} \& \mathrm{D}$ institutions in overseas acquisitions, and improve their production level, strengthen research and development and market control ability, foster a number of strong international discourse in the part of advanced technology in the field of local enterprises. In addition, we should also pay attention to personnel training and brand building; talent is the key to the transformation and upgrading of processing trade is the fundamental driving force for enterprise innovation and brand building. To promote the transformation and upgrading of processing trade in Guangdong, we must establish and improve the Personnel training mechanism in accordance with the characteristics of processing trade, Fundamentally change the difficulty of processing trade enterprises in Guangdong: difficult to recruitment, difficult to employment, difficult to keep people. To implement Guangzhou " $10+1$ " talent project in the province, from the introduction of innovative policies to strengthen the carrier construction and oth- 
er aspects of supporting policy measures, targeted to develop measures conducive to maintaining high-end talent. We should make full use of the advantages of science and technology education and the richness of international talents in Hong Kong and Macao. We will take advantage of the Guangdong Free Trade Area system innovation and give priority to the establishment of Guangdong, Hong Kong and Macao cross-border education and personnel exchanges and cooperation demonstration area, and vigorously introduce Hong Kong and Macao Innovative talent. In the brand building, to support the change of processing trade enterprises from OEM, ODM to OBM, to improve the "national-provincial-municipal" independent brand echelon cultivation mechanism, to strengthen the regional brand of industrial clusters, to promote small and mediumsized independent brand enterprises bigger and stronger, and to cultivate a number of research and development capabilities and innovative ability of the brand enterprises. It is necessary to encourage and support the processing trade enterprises through overseas registered trademarks, hire or mergers and acquisitions of foreign brands, open up their own brand products overseas marketing channels, innovate independent brand product marketing mode.

\section{Conclusions, Limitations and Prospects}

This paper takes Guangdong as the research object, which is the coastal processing trade gathering place. The first part of the paper is the analysis of the status quo of processing trade in Guangdong. The results show that: the total processing trade in Guangdong is still ranked first in all provinces and cities in China; although the proportion of processing trade in all foreign trade in Guangdong has declined, it is still the main way of foreign trade. Foreign-funded enterprises mainly engaged in Hong Kong, Macao and Taiwan-funded enterprises are the main force in the development of processing trade in Guangdong; Guangdong processing trade market sales are mainly concentrated in Hong Kong, the United States and Japan. Then, by using the Keynes model of open economy processing trade and economic growth in Guangdong, the results show that processing trade in Guangdong has a significant role in promoting economic growth. At the same time, by using the error correction model (ECM) to analyze the short-term dynamic relationship between the import and export of processing trade and economic growth in Guangdong, the results show that the import and export of processing trade both form a positive feedback mechanism for economy growth of Guangdong and can significantly promote the economic growth of Guangdong. Finally, the paper analyzes the main problems faced by the processing trade enterprises in Guangdong; the main conclusions are: Guangdong processing trade in the global production system is in the low position of OEM; Guangdong processing trade enterprises which take the foreign capital enterprises in Hong Kong and Macao as the main body, are lack of the technical basis and internal impetus for transformation and upgrading; transfer mechanism of processing trade industry in Guangdong is not perfect.

In view of my limited time and energy, this paper mainly studies the trans- 
formation and upgrading of processing trade in Guangdong Province, and the scope of the research is limited. The research conclusions of this paper have some limitations. In the future, we can expand the scope of the study and conduct a comprehensive study on the processing trade industry across the country, hoping to further verify the conclusions of this paper. In addition, this article mainly analyzes the macroscopic factors that affect the transformation and upgrading of Guangdong processing trade, and does not carry on the further analysis from the microscopic angle; in the future, we can carry on the more comprehensive analysis in consideration of the macroscopic background and the micro level.

\section{References}

[1] Li, C. (2010) The Path Choice of Transformation and Upgrading of China's Processing Trade. Industrial Economics Research, 2010, 82-90. http://www.airitilibrary.com/Publication/alDetailedMesh?docid=16719301-201007201008250012-201008250012-82-90

[2] Wang, Z.H. and Chen, X.M. (2016) Talent Structure, Liquidity and Development of Transformation and Upgrading Small and Medium-Sized Enterprise in the Pearl River Delta. Economic management, No. 4, 36-45.

[3] Li, K.J. (2016) Supply Side Reform and China's Export Trade Transformation and Upgrading under the New Normal. Economist, 4, 96-102.

[4] Chen, E. and Liu, Q. (2007) An Empirical Analysis of Foreign Direct Investment and Economic Growth in Guangzhou. Journal of Jinan University, 29, 68-72.

[5] Yifu, L. and Li, Y.J. (2001) Necessary Amendments-A Re-Examination of the Relationship between Foreign Trade and Economic Growth. International Trade, No. 9, 22-26.

[6] Wan, Y. and Luo, J.H. (2015) An Empirical Study on the Relationship between Processing Trade and Economic Growth in China. Social Sciences in Hubei, No. 1, $102-$ 105.

[7] Xiao, Y. and Chen, M.H. (2013) An Empirical Analysis of the Impact of Processing Trade on China's Economic Growth. Journal of Hunan University of Science and Engineering, No. 12, 128-132.

[8] Fan, M.Q. and Huang, W. (2014) Research on the Evolution of China's Trade Industrial Structure Based on Global Value Chain Decomposition. World Economy, No. 2, 50-70.

[9] Yang, Z.H. (2014) Strategic Thinking on How China Becomes No.1 Trading Power. Economist, No. 6, 25-33.

[10] Liu, W.L. (2015) The Puzzle of Value Creation of Chinese Export: An Analysis Based on Global Value Chain. World Economy, No. 3, 3-28. 
Submit or recommend next manuscript to SCIRP and we will provide best service for you:

Accepting pre-submission inquiries through Email, Facebook, LinkedIn, Twitter, etc. A wide selection of journals (inclusive of 9 subjects, more than 200 journals)

Providing 24-hour high-quality service

User-friendly online submission system

Fair and swift peer-review system

Efficient typesetting and proofreading procedure

Display of the result of downloads and visits, as well as the number of cited articles Maximum dissemination of your research work

Submit your manuscript at: http://papersubmission.scirp.org/

Or contact ajibm@scirp.org 